\title{
Local actors in the co-management of mole national park and
}

\section{the impacts associated with it}

\author{
Abdul-Kadri Yahaya ${ }^{1}$ \\ Ashraf Zakaria ${ }^{1}$ \\ Bismark Yeboah Boasu ${ }^{2}$
}

\begin{abstract}
Effective management of the National Parks largely depends on a participatory approach. Hitherto, fringe communities of Mole National Park were sidelined in its management. In recent times, the participation of communities in the management of forest resources in the Mole National Park is encouraged. This study examines how actors such as chiefs, land priests, clan heads, diviners, women leaders and youth groups support conservation using resource and habitat taboos, totemic system, traditional fire belt, sacred tree species and traditional awareness creation as strategies and their impacts thereof. The study employed a concurrent triangulation mixed methods approach in data collection, analysis, and presentation. Besides questionnaire administration as a quantitative method of data collection, the study made use of Key Informant Interviews, and Focus Group Discussions as qualitative methods of data collection. Apart from the use of descriptive statistics as a component of SPSS for the analysis of quantitative data, content analysis was used for the analysis of qualitative data. The study revealed that the fringe communities endorse the chiefs and the land priests (kasawule wura) as most effective actors in the management of forest flora and fauna and the totemic system as the most effective management strategy. The study concluded that, there exists local management actors, and strategies in resource management, and fringe communities and the park are impacted positively because of community participation in park management. It is recommended that, benefit-sharing schemes should be considered and developed by park management and fringe communities since this can engender commitment to participation.
\end{abstract}

Keywords: Livelihood Empowerment, Local Actors, Co-Management, Impacts, National Park

${ }^{1}$ Department of Environment and Resource Studies, Faculty of Integrated Development Studies-Simon Diedong Dombo University of Business and Integrated Development Studies ${ }^{2}$ Department of Geography, Faculty of Social Science and Arts- Simon Diedong Dombo University of Business and Integrated Development Studies.

Received on April 9 $9^{\text {th }}, 2021 /$ Accepted on November 22 ${ }^{\text {nd }}, 2021 /$ Published online on December 19, 2021

Ghana Journal of Geography Vol. 13 (3), 2021 pages 200-230

Doi: https://dx.doi.org/10.4314/gjg.v13i3.9 


\section{Background}

Forests are managed for several reasons. Among these reasons is the provision of livelihoods to local communities (Sharma, 2011). In addition, the creation and management of protected areas (PAs) such as the National Parks and Sanctuaries are with the prime goal of contributing to the conservation of biodiversity (Wilkie et al., 2008). However, approaches in forest management have witnessed changes over the years (Vacik \& Lexer, 2014; Berkes, 2009). Nevertheless, the development of effective forest management strategies remains a challenge especially in areas where the forest serves as livelihood foundation for local members (Marques et al., 2014; Hays, 2017). In the quest of averting the challenges of protecting forest reserves, the natural resource management programmes continuously employed exclude strict management strategies employed by local communities (A Rocha-Ghana, 2006). This consequently generates a negative conservation results (Alkan et al, 2009). Ogra and Badola (2008) opine that an act of preventing the indigenous and fringe communities from extracting resources in the protected areas leads to conflict between the indigenes and the forest authorities. Thus, the method to guard the protected zones and restrict biodiversity utilization by nearby neighbourhoods perpetuates resentment that creates a division between the locals and the protected area managers.

Recently, scholars have noticed the relevance of collaboration in management strategies and hence suggest co-management as the best approach for effective forest management around the world (Stringer \& Holmes, 2018; Mutoko \& Shisanya, 2015; Kehinde, 2013). In other words, comanagement has been accepted and being popularized worldwide as an effective means of managing forest (Carter \& Crown, 2005; Petheram, et al., 2004; Dhungana et al., 2017; Butler \& Schultz, 2019). The co-management approach is one of the participatory natural resource management models (Kimengsi \& Ngala, 2018; Lund et al., 2018; Ribot, 2003). It focuses on 
the inclusion of the local people in the decision-making and management of forest reserves. Berkes (2009:pp.1692) defines co-management as a process of power and responsibility-sharing between the government and local communities. It is an avenue for resolving forest conflicts (Poynter, 2005). In addition, it contributes to sustainability in forest management (Mohammed et al., 2017). In a study on whether or not the co-management of Victoria's Wombat State Forest will serve the interests of the wider community in Australia, Poynter (2005) argues that a wider introduction of co-management could involve considerable costs. This is based on the fact that the local industries could collapse and eventually people will resort to either using substitute products or procure wood from alternative sources. Meanwhile, the idea to include fringe communities in protected area management intends to amplify popular participation and to promote a greater impartial and environmentally friendly disposition of local management and development.

Although co-management is subjected to cultural, political, and legal challenges (Islam et al., 2019; Matose, 2006), the challenges obstruct the local communities from better negotiation of co-management arrangements (Castro, \& Nielsen, 2001). Co-management has been identified as an innovative approach for successful forest management especially in communities of developed and developing countries where anthropogenic pressure on forest resources is extremely high (Stevenson, 2006). In Colombia, for instance, co-management has been successful in reducing conflict at the grassroots level and within the protected areas (De Pourcq et al., 2015). In Bangladesh, co-management has been successful in managing Protected Areas and especially in locations where the livelihoods of the local communities mainly depend on forest (Islam et al., 2018; Sharma, 2011). Mawa et al., (2020) observed a net increase of registered co-management compartments in basal areas in their assessment of spatial and 
temporal changes in forest structural attributes in a semi-deciduous forest in mid-western Uganda. Similarly, Stringer and Holmes (2018) advocate for an improvement in co-management as an equitable approach to Protected Area management in Madagascar. This recommendation is based on their study on co-management of protected areas and their perceived livelihood impacts. In addition, Siraj et al., (2018) argue that the involvement of the local community is the best way to save the remnant forest in Ethiopia. Mutoko and Shisanya (2015) on the other hand, advocate for an improvement in stakeholder collaboration in their attempt to provide insights into the need for sustainable forest management in Kenya.

In Ghana, although the co-management approach has become popular in the management of forest areas, Husseini, et al., (2016) observed that passive community participation still exists especially when it comes to the management of forest reserves in the Northern regions. This, they assume is due to less or no formal collaboration between the communities and the Forest Services Division, hence they advocate for the promotion of community participation in the form of awareness creation and capacity building. That is, although previous studies have concentrated on various strategies to ensure effective co-management of forest in the northern regions, there is still a lot to be done on capacity building of local communities for effective collaboration and active participation in the management of national parks in the Savannah region of Ghana where the Mole National Park is located. This park has experienced numerous co-management strategies with the inclusion of the Community Resource Management Area (CREMA). The challenge is how to get all fringe communities to accept the rules and regulations and fully participate in the management of the park. It is against this background that this study sought to investigate how community participation through local actors at all levels is contributing to the effective management of forest flora and fauna species of the Mole National Park. The following 
objectives underpin the study: To identify local community actors in the management of forest flora and fauna species; to explore natural resources management strategies of local actors in the management of forest flora and fauna in the Mole National Park by fringe communities; and finally, to examine the impacts of community participation in the management of forest flora and fauna in the Mole National Park.

\section{Conceptual Framework}

The study is guided by a conceptual framework as illustrated in Figure 1. The conceptual framework justifies that the Mole National Park is endowed with forest flora and fauna as natural resources. Besides external actors such as Wildlife Division and NGO'S, local actors such as chiefs, land priests, as well as youth and women groups are also actively involved in the management of the Mole National Park by using beliefs, taboos, norms, prohibitions, rules and regulations, and sacred grooves. It is noted that external actors use policies, laws, and by-laws in the management of the Mole National Park. This system of management is known as collaborative management. The impacts of collaborative management on the Mole National Park are increased wildlife numbers, reduced human-wildlife conflict, increased tourists' visitation, and secured wildlife. On the other hand, the impacts of collaborative management of the Mole National Park on fringe communities are livelihood empowerment, revenue generation, as well as sustainable resource use and conservation. Figure 1 is an illustration of the conceptual framework. 
Figure 1: Conceptual Framework

\section{Impacts of Co-Management on Mole National Park: \\ Increased wildlife numbers, reduced human-wildlife conflict, increased in tourist visitation, and secured wildlife}

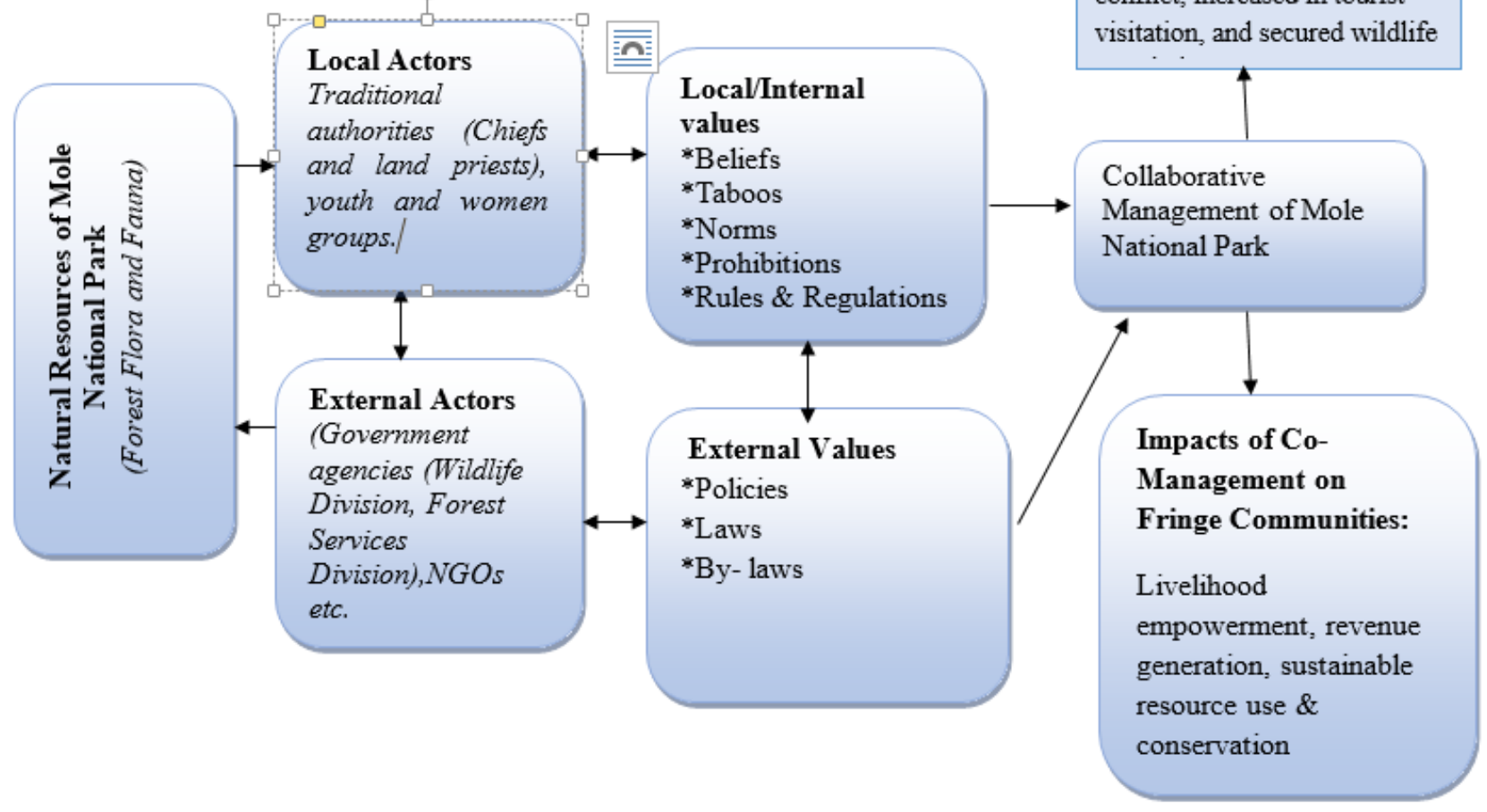

Modified from Gooch, et al (2010)

\section{Study area and Methodology}

\section{Study Area}

The Mole National Park became known in the 1930s when the area was invaded by tsetse flies. About $2,300 \mathrm{~km}^{2}$ of the present park as Game clearance to control these tsetse flies, but this exercise of game clearance was abrogated in 1957 (Mole National Park Management Plan, 2011). The Mole National Park was gazetted as a National Park in 1971 under a legislative instrument Wildlife Reserve Regulations (LI 710). The Mole National Park is the largest wildlife 
sanctuary in Ghana with a present size of $4,577 \mathrm{~km}^{2}$. It lies between $9^{\circ} 1^{\prime}$ and $10^{\circ} 10^{\prime} \mathrm{N}$, and between $1^{\circ} 22^{\prime}$ and $2^{\circ} 13^{\prime} \mathrm{W}$, between Wa and Tamale (Mole National Park Management Plan, 2011). The climate of the region is dominated by two main seasons; wet and dry seasons. The wet season has an unpredictable start, and normally ranges from late April to late October, peaking in June or July. According to the 2012 analytical report of the district profile of West Gonja (Ghana Statistical Service, 2012), an average of approximately $1144 \mathrm{~mm}$ of rainfall is recorded annually. The rainstorms are torrential, at times having a $300 \mathrm{~mm}$ fall per hour. More than $90 \%$ of the rainfall is recorded during the rainy season. Because of this, floods and erosion are common in the rainy season. The average monthly temperature is 27 degrees Celsius. The mean annual temperature of $28^{\circ} \mathrm{C}$ varies from $26^{\circ} \mathrm{C}$ in December to $31^{\circ} \mathrm{C}$ in March. The average range of temperature from day to night is $13^{\circ} \mathrm{C}$. It can be unpleasantly hot in March and April, with temperatures sometimes going up to $40^{\circ} \mathrm{C}$. During the dry season, the relative humidity of $50 \%$ and $20 \%$ for night and afternoon respectively are recorded, and in the rainy season, the relative humidity for night and afternoon has figures reaching $90 \%$ and $70 \%$ respectively. Deciduous acacia trees and other trees such as Baobab (Adansonia Digitata), Dawadawa (Parkia biglobosa), Silk Cotton (Ceiba pentrandra), Burkea Africana, Lannea acida, and Shea tree (vitellaria paradoxa) are the dominant trees. Shrubs species in the park included the jackal berry (Diospyros mespiliformis), bush weed (Flueggea Virosis), and Feretia apodanthera. The park also has some herbaceous plants, some of which are Cajanus (Atylosia Scarabaeoides), tick clover (Desmodium velutinum), Aneilema umbrosum, and Abutilon Ramosum (Sackey and Hale, 2008). Andropogon spp, Brachiaria spp, and Setaria barbata are some grasses that can be found in the park (Mole National Park Management Plan, 2011). Wild animals that are commonly seen in the park include Elephant, Kob, Waterbuck, Bushbuck, Warthog, Hartebeest, Roan antelope, 
Buffalo, Duiker, Oribi, Baboon, Patas monkey, and Green monkey (Mole National Park Management Plan, 2011). Figure 2 is a map of the Mole National Park indicating the study communities.

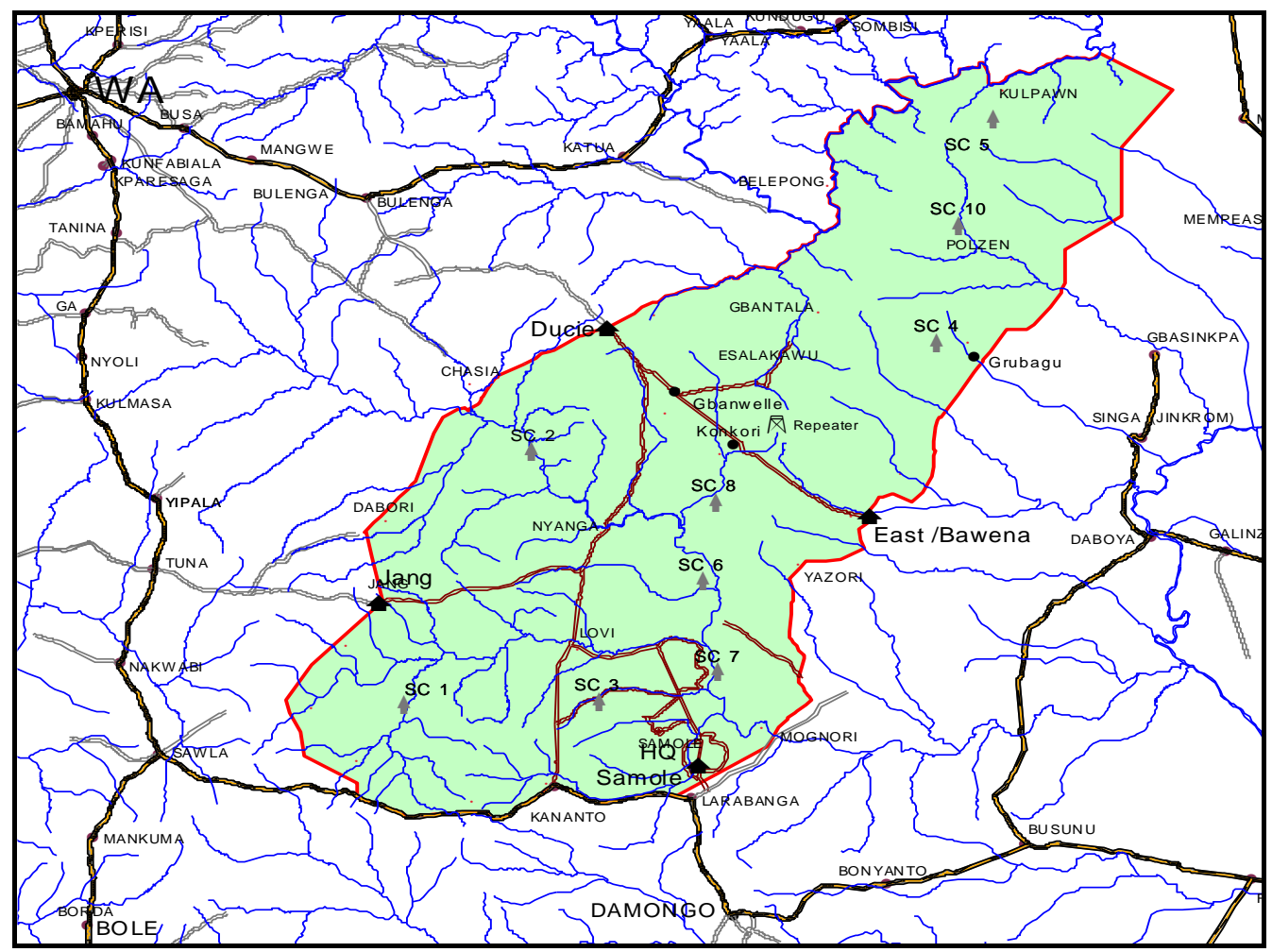

Figure 2: Map of the Mole National Park

\section{Socio-Economic Characteristics of Study Communities}

The three sampled study communities have fully embraced the CREMA initiative. CREMA means Community Resource Management Area. The socio-economic characteristics of the study communities are presented as follows:

\section{Socio-Economic Characteristics of Larabanga}

Larabanga is the heart of the West Gonja district in the Savannah Region of Ghana. It is located in the western part of Damongo. It is $15 \mathrm{~km}$ away from Damongo. Larabanga is predominantly 
occupied by Kamaras. It is however noted that some of the inhabitants are Gonjas. The community is a farming community suggesting that, Larabanga is an agrarian community. The traditional authority of the village is the council of 12 elders, and the council is presided by the Chief Imam, who is the spiritual leader of the community, assisted by the Chief of the village, and the "Tingkpema", who controls the integrity of the environment. The natives of Larabanga generate revenues from other activities, such as pottery, basketry, wood carving, manufacturing of hoe handles and catapults, blacksmithing, rope weaving, processing of medicinal herbs, tapping of honey, shea nuts processing, oil and soap making, and gari processing. Larabanga is also a Centre for international and local tourism due to its endowment with the mystical stone and ancient mosque (Museums and Monuments Board, 2009).

\section{Socio-Economic Characteristics of Murugu}

Murugu is $16 \mathrm{~km}$ away from the headquarters of the Mole National Park and situated at the South-Eastern boundary of the park. Murugu is within the West-Gonja District of Ghana's Savannah Region. The road linking the Mole National Park to Murugu is a third-class road. It is one of the communities on the Larabanga-Daboya road. The ethnic groups that make up the Murugu community are the Hanga who are about $90 \%$ of the population in the community, constituting the majority. On the other hand, the minority ethnic groups are the Gonja, Dagaba, Fulani, and Kamara. Land ownership in the Murugu community is communal. Thus, lands are under the custody of the earth priest (Tendana) but held in trust of the chief of Murugu on behalf of the paramount chief (Yagbon Wura). The community is dominated by farm/hunter families engaged in agriculture. Farming in the Murugu community is seasonal, household-based, labour intensive and dominated by women (A Rocha-Ghana, 2006). 
Ghana Journal of Geography Vol. 13 (3), 2021 pages 200-230

\section{Socio-Economic Characteristics of Kananto}

Kananto is situated along the Larabanga-Sawla road. Its geographical coordinates are 9' 14' 0', North and 2"' 0' 0"' West. Kananto is a Gonja community. However, minority ethnic groups in Kananto are Kamara and Fulani. It is also dominated by farm/hunter families engaged in agriculture and hunting. Therefore, the majority of the people of Kananto are into the rearing of livestock such as cattle, sheep, and goats as well as cultivation of maize, yam, cassava and millet. A few of the natives of Kananto are into charcoal production. Ownership of land in Kananto is communal under the custody of the earth priest (Tendana). This explains why, every member of the extended family has the right to access the communal land. This leads to farm sub-divisions and fragmentation into scattered holdings (A Rocha-Ghana, 2006).

\section{Methodology}

The methodology of the study takes into consideration research design, sources of data, sampling, data collection methods and tools, as well as techniques of data analysis and presentation.

\section{Research design}

The study resorted to a mixed research approach. This is a blend of qualitative and quantitative methods (Agresti and Finlay, 2009). Trochim (2006) points out that to do good research, qualitative and quantitative methods should be employed since qualitative methods allow for an elaborate description of events. The quantitative methods on the other hand are good at summarizing data and making a generalization. 


\section{Sources of data}

The study resorted to both primary and secondary sources of data. The study generated data originally from the field. The collection of primary data was carried out through Key Informant Interviews with chiefs of the three study communities, representative of wildlife division, management staff of the Mole National Park, representative of CREMA executive committee, as well as representative of Arocha-Ghana. Other sources of primary data were household questionnaire administration and Focus Group Discussions.

The study also resorted to documented sources for supplementary data. Such sources include the profile of the Mole National Park, published articles, text-books, and other relevant documents. The park management made available records of history and as well as management activities of the park.

\section{Sampling}

\section{Target population}

The target population of this study consisted of people living in communities fringing the Mole National Park. The three villages where data were collected were Larabanga with a population of 4308, Murugu with a population of 1220, and Kanato with a population of 586 (GSS, 2012).

\section{Sample size}

A total of 98 questionnaires were administered in the three selected communities. The sample size was determined using the formula developed by Yamane in $1967 ; \mathrm{n}=\frac{\mathrm{N}}{1+\mathrm{N} *(\mathrm{e})^{2}}$

Where; $\mathrm{n}$ designates sample size 
$\mathrm{N}$ designates the total population of each of the three selected communities e designates the margin of error which is $10 \%$ given a confidence interval of $90 \%$. The sample size of the study communities is computed as follows.

Table 2: Communities, Population and Calculated Sample size

\begin{tabular}{lll}
\hline Community & Population & computed sample size \\
\hline Larabanga & 4308 & 69 \\
Murugu & 1220 & 20 \\
Kananto & 586 & 9 \\
Total & 6114 & 98 \\
\hline
\end{tabular}

Source: Author, 2020.

Apart from the computed sample size of 98 households, Key informants consisting of management staff of the Mole National Park, a representative of A Rocha- Ghana, a member of the CREMA executive committee, a chief from each of the three communities, and a representative of Wildlife Division were interacted with for qualitative data. Three Focus Group Discussions comprising a blend of males and females who are farmers and practice conservation of forest flora and fauna were held in the three study communities. In each study community, a Focus Group Discussion was organized.

\section{Sampling techniques}

The study employed probability and non-probability sampling techniques. Specifically, purposive sampling and simple random sampling techniques were employed.

\section{Purposive sampling}

The three study communities out of many communities fringing the Mole National Park were selected using purposive sampling. Larabanga Community was chosen because the community is the gateway to the Mole National Park and is a tourist destination due to its endowment with the 
mystic stone and the historic ancient mosque. Murugu community was also picked for the fact that it is actively involved in the community resource management area (CREMA) initiative. Kananto community was selected because it is between the Mole National Park and the 'Kenikeni' forest reserve. The inhabitants of Kananto are constraint with regard to space for farmlands. Purposive sampling was also employed to select Key Informants by virtue of the fact that they are knowledgeable on the subject matter and are instrumental in the implementation of policies and standards on sustainable management of the Mole National Park.

\section{Simple random sampling}

The study adopted the random numbers method with the aid of the random numbers table as a component of simple random sampling to select the houses in the three study communities for questionnaire administration. Household heads were targeted for the questionnaire administration. One of the most convenient ways of creating a simple random sample is the random numbers method. Simple random sampling is the most elementary and customary kind of sampling method employed in quantitative scientific discipline and research generally. The best thing about the simple random sample is that every member of the population has an equal chance of being selected for the study (Ghauri and Gronhaug, 2005). By implication, it pledges that the sample chosen is representative of the population from which the sample is chosen in an unbiased way.

Disadvantages related to simple random sampling include a whole frame (an inventory of all units within the whole population) is needed; the cost of obtaining the sample will be high if the unit is geographically widely scattered; and the standard errors of the estimators can be high (Ghauri and Gronhaug, 2005). 
Ghana Journal of Geography Vol. 13 (3), 2021 pages 200-230

\section{Data Collection Methods and Tools}

The study employed household questionnaire administration, key informant interviews, and focus group discussions as data collection methods.

\section{Household Questionnaire Administration}

To assess the present and possible level of community participation in forest flora and fauna management in the communities fringing the Mole National park, a set of household questionnaires were administered to household heads. The questionnaires were designed to obtain information on local actors and local management strategies, as well as impacts of community participation in forest flora and fauna management.

\section{Key informant interviews}

Key informants consisting of management staff of the Mole National Park, a representative of A Rocha- Ghana, a member of the CREMA executive committee, a chief from each of the three communities, and a representative of Wildlife Division were interviewed for qualitative data.

The key informants are involved in making and implementing rules and regulations in the sustainable management of forest flora and fauna. Opinions on community participation and how communities engage in the management of the park was sought from these respondents. This technique often uses the approach of the semi-structured interview because it is more economical, providing a secured foundation for generalization, and requiring relatively lesser skill on the part of the interviewer. The selection of the informants was based on their direct involvement with the conservation activities. 


\section{Focus Group Discussions}

Three Focus Group Discussions were held in the three study communities. Thus in each community, a focus group discussion comprising a blend of males and females was held with farmers who are also conservationists with the aid of a Focus Group Discussion Guide. The membership of each group was eight (four males, four females).

\section{Data Analysis and Presentation}

Quantitative data were coded and entered into a component of Statistical Package for Social Sciences (SPSS) version 20 known as descriptive statistics. Qualitative data from key informant interviews and focus group discussions were analyzed using content analysis since the technique is systematic and applicable for compressing many words of text into a few categories.

Results from quantitative data are presented in tables, frequencies, and percentiles to ease explanation and discussion of the findings while qualitative data are presented as quotations to support the reported quantitative data.

\section{Results and Discussion}

The results of the study were presented and discussed in line with the study objectives. They are as follows:

\section{Local Community Actors in the Management of Forest Flora and Fauna of the Mole National Park}

The Mole National Park has at its peripheries about 33 communities. Some of which were relocated and therefore still have some ties with the park and the community members would like to access the facility and the resources just like they did previously. However, allowing them access could lead to overexploitation of forest flora and fauna resources; therefore, the existence of the local actors to check and control this possible menace is of great positioning. The 
respondents were asked whether they knew which local actors were responsible for assisting the mole national park in the management of forest flora and fauna species. The summary of the findings is shown in Table 1. Results in Table 1 shows that the chiefs and the 'Kasawule-wura' (land priests) are the major community actors that help in the management of forest flora and fauna in and around mole national park. About 46(46.9\%) of the respondents expressed confidence in the chiefs' ability to ensure that communities fringing the park contribute in diverse ways in the management of forest flora and fauna. Likewise $23(23.5 \%)$ of the respondents indicated that the second community actor that contributes to the effective management of forest flora and fauna in the park is the 'kasawule-wura' (land priests). The two actors, that is the chief and the "kasawule-wura has a total of 69 respondents representing $70.4 \%$ posing confidence in their contribution to the management of forest flora and fauna in the mole national park and this buttresses earlier research findings such as Mohammed-Katerere (2004) and Bonye and Millar (2004). Mohammed-Katerere (2004), who argued that before the colonial era, social groupings in Northern Ghana were characterized by some ethnic organizations and the chief was the symbol of leadership within the community and exercised powers in collaboration with his elders. This then explains in this study, out of the 98 people surveyed, 46(46.9\%) respondents indicated chiefs are local actors responsible for the management of forest flora and fauna. Bonye and Millar (2004) showed that the Tindanas' (land priests) operate as spiritual leaders of the communities and hold powers to land in Northern Ghana and this was confirmed in this current study where respondents mentioned 'kasawule-wura (land priest) as the secondhighest actor responsible in managing forest flora and fauna in Mole National Park.

The clan heads as indicated by $7.1 \%$ of respondents, diviners as indicated by $8.2 \%$ of respondents, women leaders as indicated by $2.0 \%$ of respondents and the youth groups as 
indicated by $12.2 \%$ of respondents are also actors in the conservation of forest flora and fauna of Mole National Park but little confident is posed in them in terms of having the ability to actively participate in the management forest flora and fauna in the Mole National Park.

The chief together with his elders intermittently during public durbars in the community remind the community members of the cultural ethos and the need to adhere to them" and ensures full implementation of the sanctioning regime on offenders (FGD, Larabanga).

I play a pivotal role when it comes to the management of forest flora and fauna species by embarking on regular sensitization exercises during communal gatherings (KII, Chief -Larabanga).

Table 1. Local actors in the management of forest flora and fauna

\begin{tabular}{lll}
\hline Actors & Frequency & Percent (\%) \\
\hline Chiefs & 46 & 46.9 \\
'Kasawule-wura' (land priests) & 23 & 23.5 \\
Clan heads & 7 & 7.1 \\
Diviners & 8 & 8.2 \\
Women leaders & 2 & 2 \\
Youth groups & 12 & 12.1 \\
Total & 98 & 100 \\
\hline
\end{tabular}

Source: Field study, 2020

Local Management Strategies Employed by Fringe Communities of Mole National Park

The current study revealed that the community actors together with the people in the fringe communities have some management strategies that are used in the protection and conservation of forest flora and fauna in the Mole National Park and the results are presented in Table 2. From the results in Table 2, 52(53.3\%) of the respondents indicated that the totemic system is widely used in the fringe communities for the protection and conservation of forest flora and fauna species. Communities around the park have adopted some animal species as totems and therefore neither kill nor eat them. The animals are python and lion. In addition, communities conserve some tree species as sacred groves and about $16(16.3 \%)$ of the respondents indicated that this is 
practised in their communities. Again 16(16.3\%) of the respondents indicated their active participation in management using traditional fire belts as a management strategy. Also, $8(8.2 \%)$ of respondents indicated that traditional awareness creation is also used in their communities as a way of managing forest flora and fauna. Adom (2016) indicated that many countries have used prehistoric conservation practices such as education and awareness crusades, documentation, and functional involvement of the stakeholders of the traditional knowledge, traditional totemic systems, sacred grove conservation strategy, and many different techniques in the management of natural resources. If these strategies are recognized and integrated into the conventional methods then countries would achieve the Aichi Biodiversity target eighteen. Interactions with the participants during the focus group discussion indicated that they respect and show some reverence to some animals such as the python ('k'galmu') and the lion ('kirmei').

When a person from a different community is seen killing a totemic animal, the animal is ceased and buried just as we do to humans (FGD, Kananto).

Wildlife animals such as python and lion are considered as totemic animals in our community. As such, we do not kill them nor hunt them (KII, Chief-Kananto)

Table 2. Strategies used by fringe communities in forest flora and fauna management.

\begin{tabular}{lll}
\hline Management strategy & Frequency & Percent $(\%)$ \\
\hline Natural and Habitat taboos & 6 & 6.1 \\
Traditional Totemic system & 52 & 53.1 \\
Traditional Fire Belts creation & 16 & 16.3 \\
Sacred tree species & 16 & 16.3 \\
Traditional Awareness Creation & 8 & 8.2 \\
Total & 98 & 100 \\
\hline
\end{tabular}

Source: Field study, 2020

\section{Impacts of Community Participation in Forest Flora and Fauna Management}

Computing the impacts of conservation interventions is problematic (Baylis et al., 2016). This could be because some impacts being intangible and cannot be quantitatively estimated. 
The statements below are what some participants said in response to the impacts on community members when they accepted to participate in the Mole National Park management activities.

We were provided with beehives, apparels for harvesting honey and we were also given some training on how to harvest honey without using fire, and in fact, we are making money out of this to support our families (FGD, Murugu).

We are allowed entry into the park yearly with the support of the park administration to perform some traditional rites at sacred groves that are found inside the park following the laid down procedures of the park and this is only possible through a collaborative effort of the park and the community (KII, Murugu Chief).

This type of satisfaction of getting an opportunity to visit traditional grounds to perform sacrifices cannot be quantified as contented by Baylis et al. (2016). Another study by Ameha et al (2014) as well as Gelo and Koch (2014) indicated that the impact of community participation in natural resource management is mixed, impacts could be negative or positive and the narratives below affirms that.

Their participation cause conflicts as a result of divergent goals, whereas the park management always insisted on conservation, many opinion leaders seek exploitation at the expense of the environment (KII,Management Staff- MNP).

\section{Impacts of local participation and relevance on fringe communities}

The study sought to understand why the fringe communities of the Mole National Park participate in the management of forest flora and fauna. A series of questions were asked in the focus group discussions conducted, and in the questionnaire administration. Respondents were first asked whether they receive any direct or indirect benefits from the conservation of forest flora and fauna of the Mole National Park because of their participation in forest flora and fauna management. They touched on economic benefits, socio-cultural benefits, spiritual benefits, peaceful co-existence with management of the Park and physical benefits. The questionnaires administered also made room for respondents to rank the impacts of their participation in forest flora and fauna management in the various communities and the results are presented by cross- 
tabulation in Table 3. People living in communities fringing the Mole National Park are motivated to participate in the management of forest flora and fauna. This motivation is about how their lives are impacted by the existence of the park. The study focused on exploring what motivates their participation most. From Table 3, 80(81.6\%) of the respondents across the three communities mentioned economic impacts as the most relevant factor that motivates their participation, 68(69.4\%) of respondents indicated physical impact. Respondents who mentioned peaceful coexistence with the staff of the Mole National Park stood at 63(64.3\%). Then 35(35.7\%) and 33(33.7\%) respondents indicated spiritual and cultural impacts respectively as their motivation to participate in forest flora and fauna management of the Mole National Park.

Buttressing on the economic impacts of community participation in the management of forest flora and fauna species of Mole National Park, a key informant had this to say "inhabitants of CREMA communities have been given training and logistical support on bee-keeping and honey harvesting as an alternative livelihood activity. This will help them generate income to support their families instead of hunting wildlife animals of the park" (KII-CREMA Executive Committee Representative).

Table 3. Cross-tabulation between Impacts and relevance on fringe communities

\begin{tabular}{lllll}
\hline Impacts & Not relevant & Relevant & Moderately Relevant & Very Relevant \\
\hline Economic & & $4(4.1 \%)$ & $14(14.3 \%)$ & $80(81.6 \%)$ \\
Socio-Cultural & $1(1.0 \%)$ & $14(14.3 \%)$ & $50(51 \%)$ & $33(33.7 \%)$ \\
Spiritual & $33(33.7 \%)$ & $16(16.3 \%)$ & $14(14.3 \%)$ & $35(35.7 \%)$ \\
Physical & $5(5.1 \%)$ & $15(15.3 \%)$ & $10(10.2 \%)$ & $68(69.4 \%)$ \\
Peaceful Coexistence & & $11(11.2 \%)$ & $24(24.5 \%)$ & $63(64.3 \%)$ \\
\hline
\end{tabular}

Source: Field study, 2020

Concerns on impacts and relevance of forest flora and fauna on fringe communities resulting from collaborative management are presented in Table 4 which reveals that the general mean of the responses from the three communities is 8.56 , with a total standard deviation value of 2.173 . 
This implies that the communities generally agree to the impacts and relevance of participating in the forest flora and fauna management to their communities. The low standard deviation value of 2.173 is indicative that respondents were consistent in their responses to all items responded to, thus the mean is close to the true situation in the fringe communities of the Mole National Park.

Table 4. Descriptive table of impacts and relevance on fringe communities

\begin{tabular}{llll}
\hline Community & $\mathrm{N}$ & Mean & Std. Deviation \\
\hline Murugu & 20 & 7.4 & 1.353 \\
Kananto & 9 & 9.22 & 2.224 \\
Larabanga & 69 & 8.81 & 2.264 \\
Total & 98 & 8.56 & 2.173 \\
\hline
\end{tabular}

Source: Field study, 2020

Impacts and Relevance of Community Participation in the Management of Forest Flora and Fauna in Mole National Park

The study also engaged respondents to unravel why the Mole National Park despite many years of operation is now engaging members of fringe communities in the management of the park. Household respondents to the questionnaires were tasked to rank the relevance of the impacts on forest flora and fauna in the Mole National Park which were enumerated. The responses have been cross-tabulated in table 5 . The results of Table 5 indicate that $90(91.8 \%)$ of respondents said that there was an increase in wildlife population due to community participation in forest flora and fauna management. Another impact of community participation in forest flora and fauna management as indicated by $61(62,25 \%)$ of respondents was secured wildlife population due to reduced poaching. When wildlife populations are secured leading to population rise, it would consequently attract tourists into the landscape of which $81(82.7 \%)$ of the respondents indicated to be relevant among the impacts of community participation in park management. The 
remaining $40(40.8 \%)$ and $28(28.6 \%)$ of respondents indicated reduced human-wildlife conflicts and easy monitoring of forest flora and fauna respectively.

Table 5. Cross-tabulation between impacts and relevance on forest flora and fauna in the Mole National Park

\begin{tabular}{lllll}
\hline Impacts & $\begin{array}{l}\text { Not } \\
\text { relevant }\end{array}$ & Relevant & $\begin{array}{l}\text { Moderately } \\
\text { relevant }\end{array}$ & $\begin{array}{l}\text { Very } \\
\text { relevant }\end{array}$ \\
\hline Increased Wildlife numbers & & & $8(8.2 \%)$ & $90(91.8 \%)$ \\
Reduced Human-Wildlife conflict & $3(3.1 \%)$ & $20(20.4 \%)$ & $35(35.7 \%)$ & $40(40.8 \%)$ \\
Increased tourists' visitation & $1(1 \%)$ & $3(3.1 \%)$ & $13(13.3 \%)$ & $81(82.7 \%)$ \\
Secured Wildlife population & $2(2 \%)$ & $12(12.2 \%)$ & $23(23.5 \%)$ & $61(62.2 \%)$ \\
Easy in monitoring Wildlife & $17(17.3 \%)$ & $28(28.6 \%)$ & $25(25.5 \%)$ & $28(28.6 \%)$ \\
\hline
\end{tabular}

Source: Field study, 2020

On issues of impacts and relevance on forest flora and fauna arising from community participation in resource management, Table 6 reveals that the general mean of the responses from the three communities is 8.05 , with a total standard deviation value of 1.863 . One can infer that the communities generally agree to the impacts of participation and level of relevance on forest flora and fauna in the park.

Table 6. Descriptive table of impacts and relevance on forest flora and fauna in the study area

\begin{tabular}{llll}
\hline Community & $\mathrm{N}$ & Mean & Std. Deviation \\
\hline Murugu & 20 & 6.85 & 1.565 \\
Kananto & 9 & 9.33 & 2.449 \\
Larabanga & 69 & 8.23 & 1.699 \\
Total & 98 & 8.05 & 1.863 \\
\hline
\end{tabular}

Source: Field study, 2020 


\section{Species Richness and Evenness in Distribution of Wildlife Animal Species in the Mole National Park}

The Shannon Wiener and Simpson Indices were employed to measure the impact of community participation in the conservation of wildlife animal species of the Mole National Park based on statistics of wildlife animal survey of the Mole National Park in the year 2019.

(a) Shannon index $(\mathrm{H})=-\sum_{\mathrm{i}=1}^{\mathrm{s}} \mathrm{Pi} \ln \mathrm{Pi}$

$\mathrm{H}=-(-1.5539)=1.5539$

$\mathrm{H}=1.5539$

Shannon Wiener Index of 1.5539 means that based on the 2019 animal survey, the Mole National Park is rich in species of wildlife animal. This is because the values of the Shannon Diversity Index for real communities fall between 1.5 and 3.5.

(b) Simpson's Index (D) $=\frac{1}{\sum_{i=1}^{n} P i^{2}}$

$$
\begin{aligned}
& \mathrm{D}=\frac{1}{0.2610} \\
& \mathrm{D}=3.8314
\end{aligned}
$$

Simpson's index of 3.8314 means that wildlife animals are evenly distributed in the Mole National Park. Table 7 is an illustration of computation of species richness and relative abundance of wildlife animal species of Mole National Park. 
Table 7 Species richness and evenness in the Mole National Park

\begin{tabular}{lccccc}
\hline Species & $\begin{array}{c}\text { Number Of } \\
\text { Individuals }\end{array}$ & $\mathrm{Pi}=\mathrm{n} / \mathrm{N}$ & $\mathrm{Pi}^{2}$ & In Pi & $\mathrm{Pi}$ In Pi \\
\hline Elephant & 436 & 0.0551 & 0.003 & -2.8986 & -0.1597 \\
Buffalo & 1392 & 0.1761 & 0.031 & -1.7367 & -0.3058 \\
Warthog & 126 & 0.0159 & 0.0003 & -4.1414 & -0.0658 \\
Waterbuck & 253 & 0.032 & 0.001 & -3.442 & -0.1101 \\
Kob & 337 & 0.0426 & 0.0018 & -3.1559 & -0.1344 \\
Bushbuck & 82 & 0.0103 & 0.0001 & -4.5756 & -0.0471 \\
Roan Ant & 2462 & 0.3116 & 0.0971 & -1.166 & -0.3633 \\
Hartebeest & 2813 & 0.356 & 0.1267 & -1.0328 & -0.3676 \\
\hline Total & 7901 & & 0.261 & & -1.5539 \\
\hline
\end{tabular}

Source: Wildlife Survey, Mole National Park, 2019

Computed values of the Shannon diversity index and Simpson's index is an indication that community participation in the management of forest flora and fauna species in the Mole National Park is making an impact as far as the conservation of wildlife animal species is concerned. A representative of Arocha Ghana in a key informant interview indicated:

statistics of the 2019 population census of wildlife animals in the Mole National Park were encouraging. In other, words, the 2019 population census of wildlife animals disclosed a massive increase in the population of wildlife animals in the Mole National Park. This may be attributed to community participation in the management of forest flora and fauna species (KII-Representative of Arocha-Ghana).

Based on the 2019 census of wildlife animals, it is an undeniable fact that the population of wildlife animals in the Mole National Park as of 2019 was comparatively greater than that of previous years (KII, Representative of Wildlife Division).

\section{Conclusions}

The study sought to unveil local community actors in the management of forest flora and fauna of the Mole National Park focusing on the strategies employed by local actors in the management of forest flora and fauna, as well as impacts of community participation in the management of forest flora and fauna. The study established that the traditional authorities in the 
communities fringing the Mole National Park such as chiefs and land priests also function as local natural resource management actors apart from clan heads, diviners, women leaders, and youth groups. They employ some management strategies in the management of forest flora and fauna in the landscape. The study showed that the traditional leaders facilitate the customs and traditions that are aimed at protecting some forest plants and animals of the Mole National Park, as well as water bodies that have played significant roles in their lives.

The study also uncovered the roles of the local actors in the conservation of forest flora and fauna species. The 'Kasawule - wura' (land priests) are the owners of the land. They perform sacrifices and rituals to the gods of the land on behalf of the people. The chiefs also see to the daily running of their domain. They formulate laws of the area and punish people who break those laws. The study also revealed that, without the existence of these traditional leaders, there would not have been norms, and no one to enforce their implementation for members of fringe communities. All these efforts geared towards the conservation of forest flora and fauna are carried out by local actors.

The study has brought to fore the traditional local management strategies used in forest flora and fauna management by the fringe communities. The study has revealed that, among the many local management strategies such as taboos, totems, traditional fire belts, sacred groves and traditional awareness creation, the fringe communities use the totemic system as their major management strategy. The majority of respondents asserted that the totemic approach was used to protect biodiversity even during the time of their great grandparents and they are still using it to protect forest flora and fauna in contemporary times.

The sustainable management of the Mole National Park depends on livelihood diversification efforts that should involve the local people engaged in economic ventures without depending on 
the Park resources for their livelihoods. The study reveals that partnership in the management of forest flora and fauna in the study area has brought many of impacts not only to the Mole National Park but also to the communities fringing the park. The collaboration has led to the direct employment of the local people. This employment package helps reduce illegal activities, therefore, boosting the wildlife population.

There is also an indication that the communities have enjoyed a peaceful co-existence with park staff since they see each other as partners in conservation for a common good. The study also disclosed that the people from the fringe communities use to see the park staff as enemies and did not like them but have come to understand that the resources belong to them and they (park staff) are only assisting the fringe communities to preserve the forest flora and fauna species for the present and the future generations.

The research also revealed that some members of the communities have been empowered to engage in profitable ventures. The organic shea business, the honey, and the recent organic cassava ventures.

The study disclosed that, when communities participate in conservation efforts, there would be an increase in wildlife population and this can consequently position the park on a world heritage map. Results on species richness and evenness in the distribution of wildlife animals based on statistics of the 2019 wildlife survey indicate that the Mole National Park is rich in wildlife animal species. The results also indicate that wildlife animals are more evenly distributed in the Mole National Park. This is an elaboration of the positive impacts of community participation. 


\section{Recommendations}

For fringe communities to participate actively in park management activities and to ensure the sustainability of the Mole National Park, the following recommendations have been outlined for policy consideration: The NGOs together with park management with the support of the District Assemblies in the landscape should help document local institutional policy; the absence of local institutional policy documents and alliances limits the extent of intervention. Legal frameworks if made available are also vital to ensure the responsibility and transparency of all interested parties.The study, also recommended that the District Assemblies in the landscape which are part of local government and an agent of government should partner with the park in making by-laws that are in tune with these strategies that are geared towards protection and preservation of biodiversity in the Mole National Park.

It is also recommended that the park management through the community collaboration units should educate the traditional leaders on policies and conventions on biodiversity conservation that are implemented in managing the forest flora and fauna in the park.

For the Mole national park to earn the trust of surrounding communities to dedicate more of their time and attention to participate in management activities, managers in charge of community collaboration should be motivated and lead the way to charting legal systems for benefit-sharing since this could fortify the commitment towards sustainable forest flora and fauna management. They should chart this course by designing programs together with surrounding communities and reach out to those communities interested to participate in management activities.

There should be an increase in collaboration between park management and the surrounding communities. Information about the park and its activities should be made known to all the 33 
communities fringing the park and this has to be consistent among all communities to increase their interest and help reduce conflicts and enhance the communities' understanding of park conservation efforts. Management of the Mole National Park should sustain the existing partnership with environmental NGOs whose focus is on community development, to assist the park in building capacities of the surrounding communities in alternative livelihood programs. With the help of these NGOs, potential eco-tourism attractions within the communities can be developed thereby providing economic ventures for the people.

\section{References}

A Rocha-Ghana (2006): Baseline Socio-Economic Survey Report of Murugu, Mognori and Kananto Communities.

Adom D. (2016b). Inclusion of Local People and Their Cultural Practices in Biodiversity Conservation: Lessons from Successful Nations. American Journal of Environmental Protection 4(3): 67-78.

Agresti, A.and Finlay, B. (2009) Statistical Methods for Social Science (Fourth Edition) Pearson Prentice Hall, New Jersey, USA.609 pp.

Alkan H., Korkmaz M., \& Tolunay A., (2009). Assessment of Primary Factors Causing Positive or Negative Local Perceptions on Protected Areas, Journal of Environmental Engineering and Landscape Management, 17:1, 20-27.

Ameha, A., Nielsen, O.J. \& Larsen, H.O. (2014). Impacts of Access and Benefit-Sharing on Livelihoods and Forest: Case of Participatory Forest Management in Ethiopia. Ecol. Econ., 97, 162-171.

Baylis, K., Honey-Rosés, J., Börner, J. Corbera,E., Ezzine-de-Blas, D., Ferraro, P. J., Lapeyre, R., Persson, U, M., Pfaff, A., and Wunder, S. (2016). Mainstreaming Impact Evaluation in Nature Conservation. Conserv. Lett., 9, 58-64.

Berkes, F. (2009). Evolution of Co-Management: Role of Knowledge Generation, Bridging Organizations and Social Learning. Journal of environmental management, 90(5), 16921702.

Bonye, S. and Millar, D. (2004), Traditional Institutions: Entry Points for Endogenous Development. Compass Magazine for Endogenous Development, No.7. 
Butler, W. H., \& Schultz, C. (2019). Conclusion-The Future of Collaborative Forest Restoration: Scholarship, Policy, and Practice. In A New Era for Collaborative Forest Management (pp. 217-235).

Carter, J., \& Gronow, J. (2005). Recent Experience in Collaborative Forest Management: A Review Paper.

Castro, A. P., \& Nielsen, E. (2001). Indigenous People and Co-Management: Implications for Conflict Management. Environmental Science \& Policy, 4(4-5), 229-239.

De Pourcq, K., Thomas, E., Arts, B., Vranckx, A., Léon-Sicard, T., \& Van Damme, P. (2015). Conflict in Protected Areas: Who Says Co-Management Does Not Work? PLoS One, 10(12), e0144943.

Dhungana, S. P., Satyal, P., Yadav, N. P., \& Bhattarai, B. (2017). Collaborative Forest Management in Nepal: Tenure, Governance and Contestations. Journal of Forest and Livelihood, 15(1), 27-42.

Gelo, D. \& Koch, S. F. (2014). The Impact of Common Property Right Forestry: Evidence from Ethiopian Villages. World Dev., 64, 395-406.

Ghana Statistical Service. (2012). 2010 Population and Housing Census: District Analytical Report, West Gonja District. Accra, Ghana.

Ghauri, P. \& Gronhaug, K. (2005). Research Methods in Business Studies, Harlow, FT/Prentice Hall.

Gooch, C.,Darier, E. de Marchi. B., Funtowicz, S., Grove-White, R., Pereira, A.G., Shackley, S. and Wynne, B. (2010). Context of Citizens Participation. Cambridge University Press. Cambridge. Pp 37-61.

Hays, Q. R. (2017). Working to Address Complex Forest Issues: A Collaborative Case Study between the Mescalero Apache Nation and USDA Forest Service. Journal of Forestry, 115(5), 456-457.

Husseini, R., Kendie, S. B. \& Agbesinyale P. (2016). Community Participation in the Management of Forest Reserves in the Northern Region of Ghana, International Journal of Sustainable Development \& World Ecology, 23(3), 245 - 256.

Islam, K.N., Rahman, M.M., Jashimuddin, M., Hossain, M.M., Islam, K., and Al Faroque, M. (2019). Analyzing Multi-Temporal Satellite Imagery and Stakeholders' Perceptions to have an Insight into how Forest Co-Management is Changing the Protected Area Landscapes in Bangladesh. Journal of Forest Policy and Economics, Volume 101, Pages 70-80,

Islam, M. W., Ruhanen, L., \& Ritchie, B. W. (2018). Tourism Governance in Protected Areas: Investigating the Application of the Adaptive Co-Management Approach. Journal of Sustainable Tourism, 26(11), 1890-1908.

Kimengsi, J.N. \& Ngala, M.P. (2018). Revisiting Participatory Forest Management and Community Livelihoods in the Kilum-Ijim Montane Forest Landscape of Cameroon. International Journal of Global Sustainability, Vol. 2, No. 1, pp 39 - 55

Lund, J.F., Rutt, R.L., \& Ribot, J. (2018). Trends in Research on Forestry Decentralization Policies. Curr. Opin. Environ.Sustain. 32, 17-22. 
Marques, A.F., Rosset C., Rasinmaki, J., Vacik, H., Gordon, S., Nobre, S., Falcao, A., Weber D., Granitzer, M. \& Eriksson, L.O. (2014). Collaborative Development of a Semantic wiki on Forest Management Decision Support, Scandinavian Journal of Forest Research, 29:sup1, 30-43.

Matose, F. (2006). Co-management Options for Reserved Forests in Zimbabwe and Beyond: Policy Implications of Forest Management Strategies. Forest Policy and Economics, 8(4), 363-374.

Mawa, C., Babweteera, F. \& Tumusiime, D. M. (2020). Conservation Outcomes of Collaborative Forest Management in a Medium Altitude Semideciduous Forest in Midwestern Uganda, Journal of Sustainable Forestry.

Mohammed, A. J., Inoue, M., \& Shivakoti, G. (2017). Moving Forward in Collaborative Forest Management: Role of External Actors for Sustainable Forest Socio-Ecological Systems. Forest Policy and Economics, 74, 13-19.

Mohammed-Katerere, J. (2004), Participatory Natural Resource Management in the Communal Land of Zimbabwe: What Role for Customary Law? African Studies Quarterly 5, No. 3; $\mathrm{Z}$.

Mole National Park. (2011). Management plan. Damango Wildlife Division.

Museums and Monuments Board (2009): Ghana's Vanishing Past; Development Antiques and the Destruction of Archaeological Records.

Mutoko, C. M. \& Shisanya, C.A. (2015). Tropical Forest Conservation Versus Conversion Trade-offs: Insights from Analysis of Ecosystem Services provided by Kakamega Rainforest in Kenya. Journal of Ecosystem Services, Volume 14, Pages 1-11

Ogra, M., \& Badola, R. (2008). Compensating Human-Wildlife Conflict in Protected Area Communities: Ground-Level Perspectives from Uttarakhand, India. Human Ecology, 36, 717- 729.

Petheram, R. J., Stephen, P., \& Gilmour, D. (2004). Collaborative Forest Management: A Review. Australian Forestry, 67(2), 137-146.

Poynter, M. (2005). Collaborative Forest Management in Victoria's Wombat State Forest; Will it Serve the Interests of the Wider Community? Australian Forestry, 68(3), 192-201.

Ribot, J.C. (2003). Democratic Decentralization of Natural Resources. In Beyond Structural Adjustment the Institutional Context of African Development; Palgrave: Basingstoke, UK, pp. 159-182.

Sharma, R. A. (2011). Co-Management of Protected Areas in South Asia with Special Reference to Bangladesh. Asia-Pacific Journal of Rural Development, 21(1), 1-28).

Siraj, M., Zhang, K., Xiao, W., Bilal, A., Gemechu, S., Geda, K. \& Xiaodan, L. (2018). Does Participatory Forest Management Save the Remnant Forest in Ethiopia?. Proceedings of the National Academy of Sciences, India Section B: Biological Sciences, 88(1), 1-14.

Stevenson, M. G. (2006). The Possibility of Difference: Rethinking Co-Management. Human Organization, 65(2), 167-180). 
Stringer, L., and Holmes, G (2016): Changing Governance, Changing Inequalities: Protected Area Co-Management and Access to Forest Services; A Madagascar Case Study. Science Direct. Vol 30, Part A. Pp 137-148.

Trochim, W. (2006). Research Methods: The Concise Knowledge Base. Cincinnatti, OH.

UNCED 1992, Earth Summit-United Nations.

Vacik, H., \& Lexer, M. J. (2014). Past, Current and Future Drivers for the Development of Decision Support Systems in Forest Management. Scandinavian Journal of Forest Research, 29(sup1), 2-19.

Ward, C., Stringer, L. C., \& Holmes, G. (2018). Protected Area Co-Management and Perceived Livelihood Impacts. Journal of Environmental Management, 228, 1-12.

Wilkie D, Adams WM, and Redford KH (2008) Protected Areas, Ecological Scale, and Governance: A Framing Paper, Protected Areas, Governance, and Scale. Wildlife Conservation Society, Working Paper, 36 